\title{
Strategic Environmental Assessment in the Application of Preventive Protection for Wind Farm Noise-Case Study: Maestrale Ring Wind Farm
}

\author{
Boško D. Josimović ${ }^{1, *}$, Aleksandar Cvjetić ${ }^{2}$ ad and Božidar Manić $^{1}$ (D) \\ 1 Institute of Architecture, Urban \& Spatial Planning of Serbia, 11000 Belgrade, Serbia; bozam@iaus.ac.rs \\ 2 Faculty of Mining and Geology, University of Belgrade, 11000 Belgrade, Serbia; aleksandar.cvjetic@rgf.bg.ac.rs \\ * Correspondence: bosko@iaus.ac.rs
}

Citation: Josimović, B.D.; Cvjetić, A.; Manić, B. Strategic Environmental Assessment in the Application of Preventive Protection for Wind Farm Noise-Case Study: Maestrale Ring Wind Farm. Energies 2021, 14, 6174. https://doi.org/10.3390/en14196174

Academic Editors: Tomasz Boczar, Daria Wotzka and Michał Kozioł

Received: 1 September 2021

Accepted: 23 September 2021

Published: 27 September 2021

Publisher's Note: MDPI stays neutral with regard to jurisdictional claims in published maps and institutional affiliations.

Copyright: (c) 2021 by the authors. Licensee MDPI, Basel, Switzerland. This article is an open access article distributed under the terms and conditions of the Creative Commons Attribution (CC BY) license (https:// creativecommons.org/licenses/by/ $4.0 /)$.

\begin{abstract}
Determining the spatial position of wind turbines is the initial and most important phase in the development of a wind farm project. In this sensitive phase, all potential problems that may arise in the later stages of project development should be prevented by means of spatial and urban planning instruments. This makes it possible to achieve maximum use of the potential of wind in a particular space and, thus, fulfil the technical and economic requirements of the project while respecting the goals of environmental protection in that same area, through preventive protection. Therefore, it is essential, even at the earliest planning and development stage of a wind farm project, for the requirements that are important for optimal spatial solutions to be balanced. In this process, strategic environmental assessment (SEA) is a support to the planning process and an invaluable instrument for finding optimal spatial solutions for the possible key spatial impacts of wind power with regard to noise, shadow flicker, ornithofauna and chiropterofauna. The weakness of SEA can be seen in its predominant application of expert qualitative methods that bring with them subjectivity, since they depend on expert knowledge and skills. This paper presents the aspect of noise impact assessment and its inclusion in the SEA for the Maestrale Ring wind farm in Serbia. The results of the research indicate how it is possible to achieve the principle of objectivity in the process of multicriteria expert evaluation by including the results of a partial impact assessment of the noise from wind farms, using results obtained from software modeling of the spatial dispersion of wind turbine noise in the SoundPlan 8.1 software package in the SEA process. These quantitative results predicting the noise level were used in a semi-quantitative method of multicriteria evaluation in the SEA through the definition of criteria to determine the ranking of impacts, which is elaborated in the paper. The results also show the significant of the contribution of applying a methodological approach based on a combination of qualitative and quantitative evaluation methods in SEA. These methods positively affect the application of the principle of preventive protection through the optimal selection of the number and position of wind turbines on one hand and the objectivity of drawing conclusions based on which strategic decisions are made in the final phase of the SEA process, on the other.
\end{abstract}

Keywords: wind farm noise; strategic environmental assessment; preventive environmental protection; noise modeling; noise regulation

\section{Introduction}

Almost thirty years have passed since the introduction of SEA as an instrument for evaluating the consequences and impact of particular policies, plans and programs on the environment, with the purpose of ensuring that the principles of sustainable development and environmental protection are fully included in the earliest decision-making phase, on an equal footing with economic and social considerations [1]. During this period, a large number of authors have written about the significance of applying SEA to timely and optimal decision making on key development issues, in which the focus is on the issue of environmental protection [2-12]. Most of these authors are from the European continent 
and so it is no surprise that the application of SEA in European planning practice and spatial development is given great attention and it is also established through European legislation $[13,14]$.

Today, SEA is one of the most important instruments for implementing the principles of sustainable development in spatial development policy. The application of SEA in spatial development planning, through various development documents, makes it possible today to consider the consequences of proposed development concepts and spatial changes in the early conceptual stages of a planning proposal, while respecting the capacity of the space and involving the public in all phases of developing and adopting the SEA. In this context, SEA makes a significant contribution to the decision-making process with regard to the future development of a particular space [15] and it is an important instrument for implementing the concept of preventive protection [12].

Based on a review of international experiences and their own practice in the application of SEA, the World Bank and other financial institutions consider SEA to be "a participatory approach for increasing the impact of social and environmental issues on development planning, decision-making and implementation processes at the strategic level" $[16,17]$. This position of financial institutions is especially important in the wind energy sector, precisely because of the way projects are financed in this energy sector.

In addition, the European Strategic Environmental Assessment Directive 2001/42/EC stipulates that the SEA process is implemented for plans and programs in various areas, including energy and, therefore, in the field of wind energy. Although it is generally accepted that possible negative effects of wind farms on the environment exist, they are considered to be negligible compared with the positive effects. However, they should not be neglected, as indicated by EU Guidance on wind energy in accordance with the EU nature legislation [18].

In the context of considering the territorial impacts in SEA, it is especially important in the planning process to consider the dominant impacts of wind farms on: biodiversity (especially on flying fauna); the population (noise, shadow flicker effect, possible accident situations); and the landscape. Analysis of each of the mentioned territorial impacts is especially important for determining the optimal number and position of wind turbines. This analysis can be partial (the authors use the term "partial" for all assessments that analyze the impact of a particular project, e.g., wind farms, on only one environmental element (factor)) for each of the mentioned aspects of the impact, but only as an integral part of a unique impact assessment, within which a holistic approach to assessing the impact of wind farms on the environment is applied. Much has been written recently in scientific literature about partial assessment of the impact of wind farms on individual environmental elements [19-29], which is not unusual given the dynamic development of wind energy at the global level.

This paper focuses on a partial noise analysis as part of a unique impact assessment carried out within the framework of SEA for the urban plan of one of the largest planned wind farms in Europe-Maestrale Ring, in Serbia (total installed capacity approximately $700 \mathrm{MW}$ ). The spatial impact of noise from wind farms has been singled out as particularly important in the context of possible negative effects on human health, which Pedersen and Waye [30] classify into three groups: subjective effect (discomfort, disturbance and dissatisfaction); interference with certain daily activities (speech, sleep and learning); and physiological effect (anxiety, tinnitus, or in the worst case, hearing loss). Problems that have stood out in importance in practice so far relate to the acoustic impact of noise and sleep disturbance to which local populations living near wind farms are exposed [31,32]. Some authors point out that part of the problem related to noise from wind farms relates to infrasound [33-43], while others highlight the significance of low frequency sound [44,45]. After an extensive analysis of the literature, Freiberg et al. [46], in an assessment of the potential effects of wind turbines on human health, concluded that in the case of infrasound and low frequency noise generated by wind turbines, the main effects of their impact on humans are physical symptoms, health effects in general and affective influence (mood). 
However, their literature analysis also showed the absence of any results from systematic and comprehensive clinical and epidemiological studies regarding the possible effect of low frequency noise, including infrasound, on the health of people living in their vicinity. In this context, some authors [47] emphasize the importance of establishing a reference methodology for measuring and defining unambiguous criteria for assessing the acceptable impact of wind turbines. This is particularly supported by the fact that at present, in virtually every country and even in certain administrative units within a given country, there are different normative and legal acts regarding the limitations of acoustic noise emitted by wind turbines.

The wind farm noise assessment in this paper is in the context of expert multicriteria evaluation (semi-quantitative method) in SEA, with the aim of achieving objectivity in the evaluation process on one hand and on the other hand, the optimal spatial organization of 113 planned wind turbines using the principle of preventive protection, in the planning of Maestrale Ring wind farm. Definitions of the criteria for evaluating the impact of noise from wind farms were based on domestic legislation in this area that refers to the Environmental Noise Directive (2002/49/EC) [48] and the Guidelines for Community Noise (WHO, 1999) [49].

\section{Materials and Methods}

In the topographic sense, the area is flat, with altitudes from 98 to 106 masl. The boundary of the planning document for which the SEA study was conducted covers a part of the administrative territory of the city of Subotica, with an area of about 11,000 ha, near the rural settlements: Čantavir, Bikovo, Donji grad and Žednik (Figure 1). The area of the planned Maestrale Ring wind farm (case study) is located in the north of the Republic of Serbia, at a distance of about $25 \mathrm{~km}$ from the border with Hungary. The central part of the location is situated at $45^{\circ} 56^{\prime} 02.51^{\prime \prime} \mathrm{N}$ i $19^{\circ} 41^{\prime} 07.29^{\prime \prime} \mathrm{E}$ (more detailed coordinates in the Gauss-Kruger coordinate system are given in Figures 2 and 3).

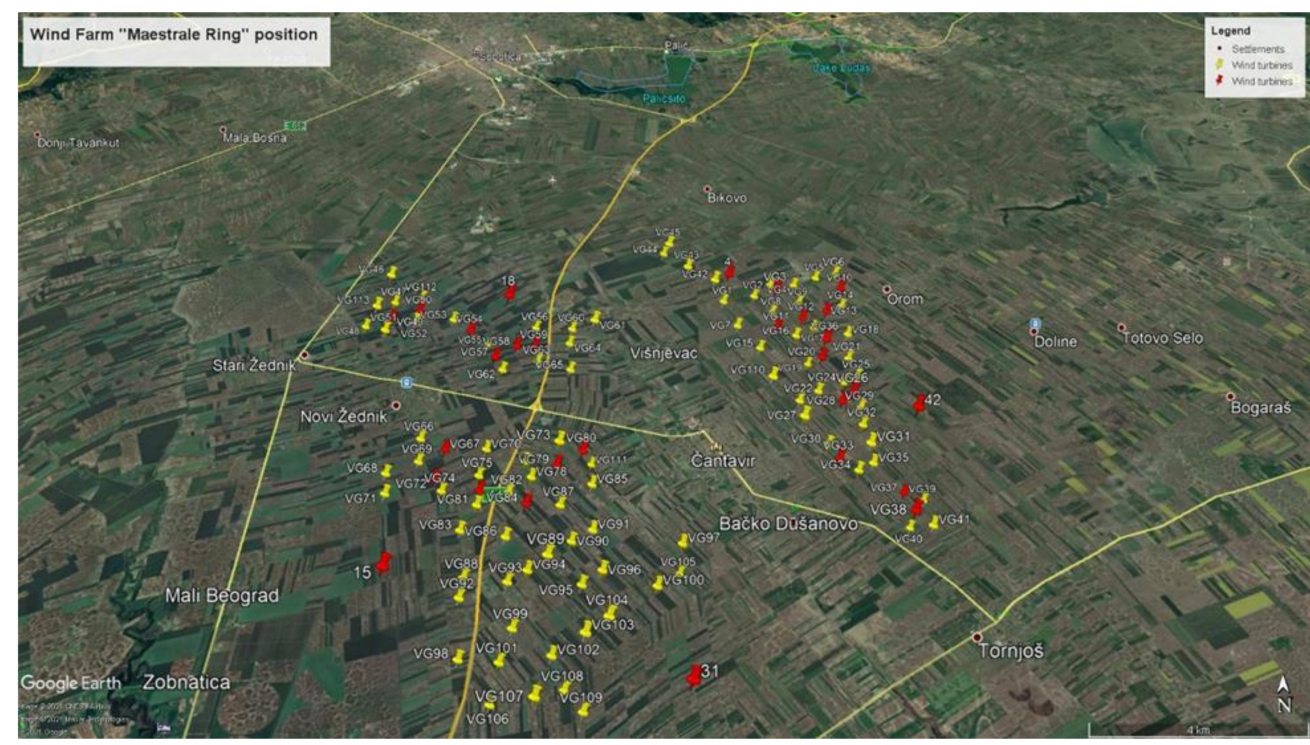

Figure 1. Position and spatial organization of the planned Maestrale Ring wind farm. (Source: Google Earth with modifications). 


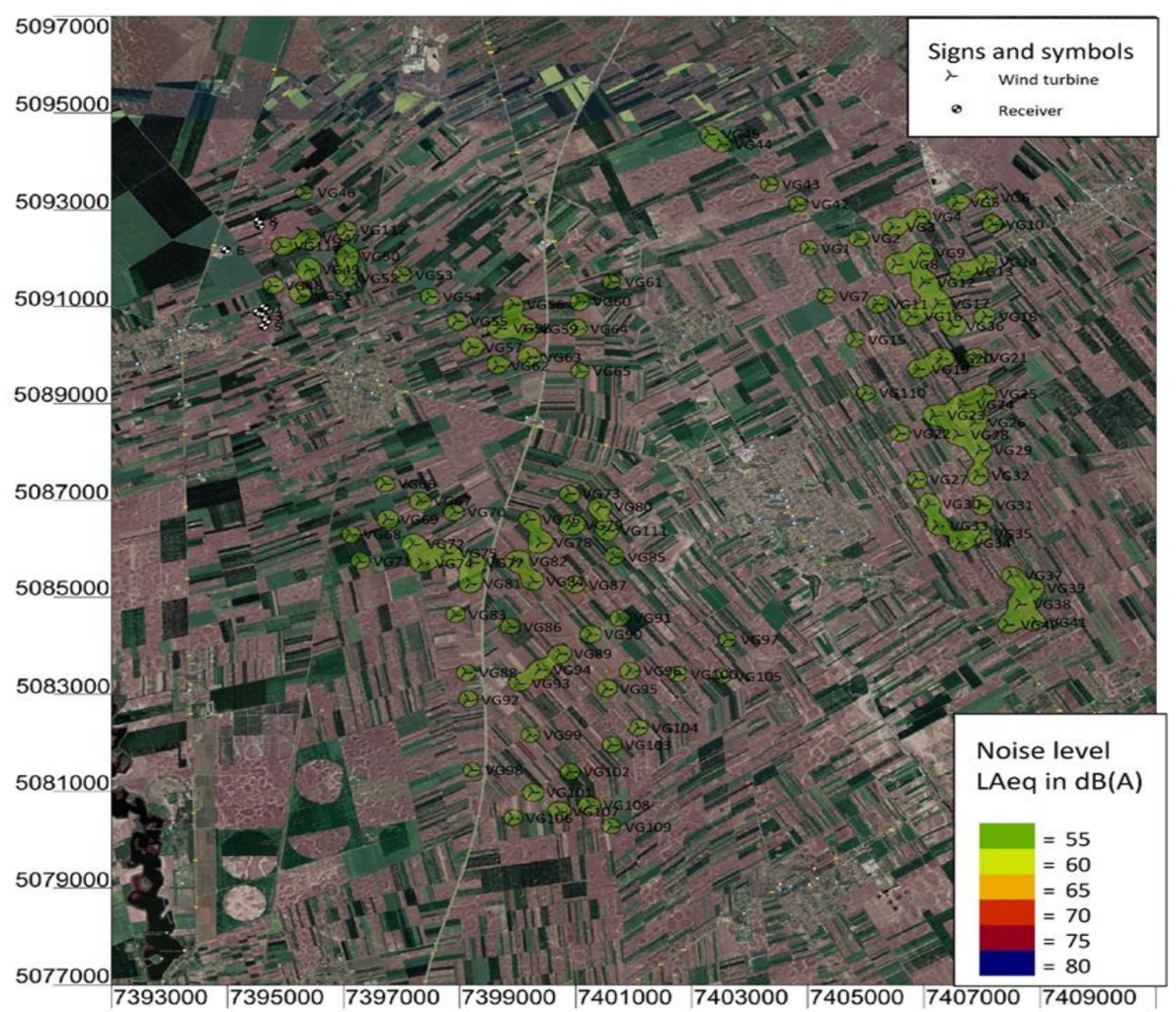

Figure 2. Results of modeling the spatial dispersion of noise for the day-evening period (coordinates are given in the Gauss-Kruger system).

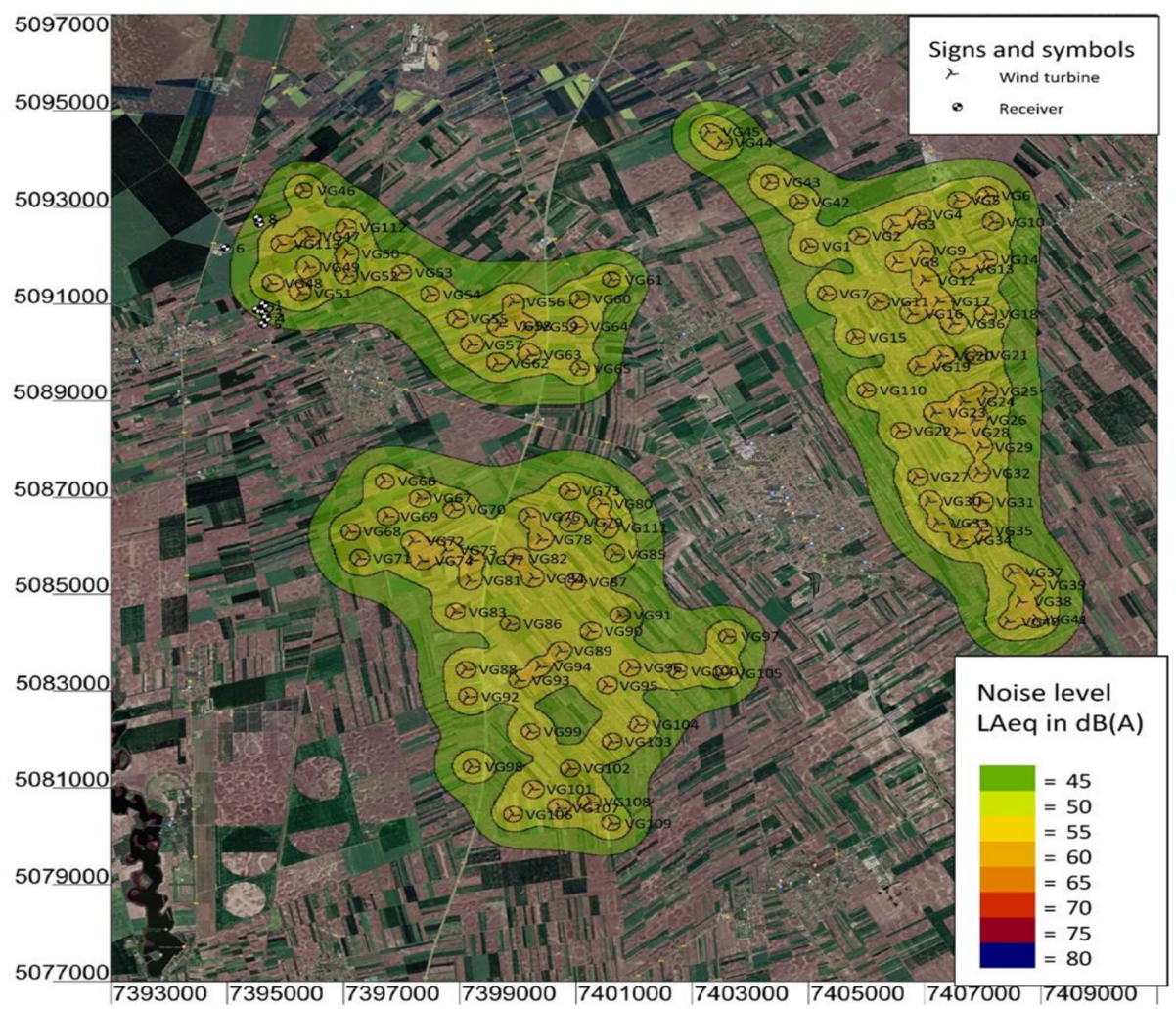

Figure 3. Results of modeling the spatial dispersion of noise for the night period (coordinates are given in the Gauss-Kruger system). 
According to the concept of the planning document, the wind farm is conditionally divided into four units within which the installation of 113 wind turbines is planned:

1. Unit 1-forms part of the wind farm northeast of the Čantavir settlement, within which 46 wind turbines are planned;

2. Unit 2-forms part of the wind farm southwest of the Čantavir settlement, within which 30 wind turbines are planned;

3. Unit 3-forms part of the wind farm north of the Stari and Novi Žednik settlements, within which 22 wind turbines are planned; and

4. Unit 4-forms part of the wind farm west of the existing E-75 highway, within which 15 wind turbines are planned.

The area that was the subject of the analysis is located on predominantly anthropogenically modified, flat agricultural land that is intersected by various existing and planned infrastructure corridors representing some of the spatial limitations for positioning the wind turbines.

The task of the SEA process for the Maestrale Ring project was to assess the significance of the impact of wind farms on the environment: biodiversity, air, water, land, climate change, landscape, cultural heritage, non-ionizing radiation, noise (which is the focus of this work), the effect of shadow flicker, accidents, infrastructure development and socioeconomic aspects of development and to optimize the position of wind turbines in relation to the results obtained.

Bearing in mind that the general approach to impact assessment in the SEA process in methodological terms is predominantly expert, qualitative and subjective, but also flexible in relation to various precise models and tools used in environmental engineering and other areas based on scientific postulates of environmental impact assessment (EIA) [50-53], the challenge was to select the appropriate techniques and methodology for assessment in the SEA process.

For SEA in planning wind farms, it is both possible and desirable to apply different qualitative expert methods in combination with quantitative methods and modeling, which are also applied for partial impact assessments (such as modeling noise and the effects of shadow flicker). In this way, it is possible to achieve objectivity in the SEA process as the earliest phase of wind farm planning and, thus, fully apply the concept of preventive environmental protection [12]. In other words, due to the specifics of planning wind farm projects, it is both possible and desirable to have a combined technical and planning approach in SEA, i.e., the application of a semi-quantitative method of multi-criteria evaluation [54].

This atypicality in the methodological approach, based on a combination of different methodological procedures, techniques and methods, is also atypical for the SEA procedure, but it is recommended wherever possible, as Mardsen [53] points out when emphasizing flexibility in SEA methodology, in order to achieve the greatest possible objectivity in the impact assessment. Namely, compared to other widely applicable impact assess-ment instruments, such as the traditional life cycle assessment (LCA), EIA and ESIA, in which different mathematical and simulation models and methods can be applied due to data decomposition, this is not usually the case in SEA. In fact, the SEA procedure is carried out at the strategic level of planning, or in the initial phase of project development (which is the case for wind farms) when there is usually no exact data that is necessary for quantitative methods, which is why the procedure usually focuses on qualitative expert methods [54].

In this particular case, the SEA for the Maestrale Ring wind farm project applied a semiquantitative method of multicriteria evaluation for the planned activities, using an expert qualitative method as a basis for its valorization for sustainable spatial development [54], combined with noise modeling and the expert quantitative statements, which served as a basis for defining the relevant evaluation criteria. The initial phase in this approach was to define the objectives and associated indicators for the SEA according to environmental receptors and the criteria for evaluating planning solutions. Illustrative Tables 1 and 2 
show an excerpt from the SEA tables relating only to the consideration of the noise aspect, which is only one of a total of 16 SEA objectives.

Table 1. Excerpt from the table "SEA objectives and indicators" related to noise. (Source: SEA for the Urban Plan of the Maestrale Ring wind farm).

\begin{tabular}{cccc}
\hline Environmental Receptor & SEA Objective & \multicolumn{1}{c}{ Indicators } \\
\hline Social factors & $\begin{array}{c}\text { 12. Reduce the population's } \\
\text { exposure to an increased level } \\
\text { of noise }\end{array}$ & - & $\begin{array}{l}\text { Number of residential buildings in the zone with } \\
\text { increased noise levels } \\
\text { The total noise indicator according to the method- } \\
\text { ology for calculating it in the rules for the national } \\
\text { list of environmental indicators }\end{array}$ \\
\hline
\end{tabular}

Table 2. Excerpt from the table "Quantitative and qualitative SEA criteria for the evaluation of noise impact". (Source: SEA for the Urban Plan of the Maestrale Ring wind farm).

\begin{tabular}{|c|c|c|}
\hline Criteria & Rank & Description \\
\hline \multicolumn{3}{|r|}{ Magnitude of Impact } \\
\hline Significant & -3 & $\begin{array}{l}\text { Significantly burdens the capacity of the space (increase in noise levels at receptors } \\
\text { over } 4 \mathrm{~dB} \text { compared to Limit values for the noise indicators (LVNI) }\end{array}$ \\
\hline Greater & -2 & $\begin{array}{c}\text { Disturbs the environment to a greater extent (increase in level of noise at receptors } \\
\text { between } 3 \text { and } 4 \mathrm{~dB} \text { compared to LVNI) }\end{array}$ \\
\hline Lesser & -1 & $\begin{array}{l}\text { Disturbs the environment to a lesser extent (increase in level of noise at receptors } \\
\text { below } 3 \mathrm{~dB} \text { compared to LVNI) }\end{array}$ \\
\hline No impact & $\mathbf{0}$ & No impact on the receptors (values of noise levels at the receptors are below LVNI) \\
\hline \multicolumn{3}{|r|}{ Spatial Dispersion of Impact } \\
\hline Municipal & $\mathbf{O}$ & Possible impact on the whole area of the municipality \\
\hline Local & $\mathbf{L}$ & Possible impact on individual locations \\
\hline \multicolumn{3}{|r|}{ Probability of Impact } \\
\hline $100 \%$ & I & Impact certain \\
\hline Greater than $50 \%$ & $\mathbf{V}$ & Impact likely \\
\hline Less than $50 \%$ & $\mathbf{M}$ & Impact possible \\
\hline \multicolumn{3}{|r|}{ Frequency of Impact } \\
\hline Occasional & $\mathbf{P}$ & Occasional impact \\
\hline Constant & $S$ & Constant impact \\
\hline
\end{tabular}

When formulating the objectives and indicators for assessing the impact of noise from the planned Maestrale Ring wind farm (Table 1), the following were taken into account: the "zero" condition of the noise values at the measuring point (Within the national environmental monitoring network) in the Čantavir settlement; Environmental Noise Directive (2002/49/EC) [48]; Law on Environmental Noise Protection (2012) [55]; Regulation on Noise Indicators, Limits, Methods for Evaluating Noise Indicators, Harassment and Harmful Effects of Environmental Noise (2012) [56]; Guidelines for Community Noise (WHO, 1999) [49].

Analysis of the possibilities for including primarily spatial impacts, but also the consideration of possible noise impacts from the planned Maestrale Ring wind farm, resulted in the SEA being formed with 4 groups of criteria, with a total of 11 individual criteria, relating to: size (intensity) of impact; spatial dimensions (spatial dispersion) of impact; the likelihood that some of the estimated impacts will occur in reality; and frequency (duration) of impacts (Table 2).

Application of the semi-quantitative method of multicriteria evaluation supported by software modeling of the spatial dispersion of noise from the wind farm, i.e., creating the possibility for quantitative expression of the results in the SEA, made it possible to deter-mine quantitative values for the magnitude of the impact of noise from the wind farm on receptors (objects), based on combining expert/qualitative methods of evaluation with simulation/quantitative methods, as this study shows. 
On the basis of the stated objectives, indicators and criteria, a multicriteria evaluation of all planning solutions from the Urban Plan of the Maestrale Ring wind farm was performed. In the SEA, matrices were formed in which all planning solutions were expertly evaluated in relation to the defined SEA objectives and indicators, using on the 4 groups of criteria from Table 2.

For the expert assessment of the noise impact from the planned Maestrale Ring wind farm, the results were used from a partial assessment based on modeling the spatial dispersion of the noise. Noise modeling was based on the following:

1. The permitted noise level values were, in the phase of the wind farm's operation, in line with IFC PS1 recommendations, i.e., EHS Guidelines [57];

2. Modeling was performed for 113 wind turbines. In order for the modeling to cover as wide a range of wind turbines as possible, the types of wind turbines with the most unfavorable scenario were analyzed for the mathematical model, i.e., the types of wind turbine that had the largest dimensions at that time-with the height of the turbine center at $149 \mathrm{~m}$ and the rotor diameter at $162 \mathrm{~m}$ (Vestas V 162/5,6 MW);

3. The permissible noise levels of wind turbines recommended by the World Bank were compared with the values permitted by national regulations [56];

4. The basic values used in this report to describe noise are in accordance with the conventions listed in ISO 1996-1:2016 and ISO 1996-2:2017 [58]. Accordingly, all frequency-weighted levels of sound pressure are expressed in decibels (dB) (e.g., the sound pressure levels obtained during modeling using A-frequency weighting are expressed as LA (dB).

The criteria for assessing the impact of noise on sensitive receptors recommended by the World Bank are shown in Table 3. In accordance with World Bank guidelines, when regulations in the country where the project is implemented differ from the levels and measures recommended in World Bank guidelines, it is expected that projects achieve the level required by the stricter regulations. Therefore, the values listed in Table 4 are prescribed by national regulations. In this particular case, the values of permissible noise levels for residential areas are identical.

Table 3. Recommended noise levels (World Bank) (The stated values refer to noise in the external environment, outside the building, on the facade of the building (Guidelines for Community Noise, World Health Organization (WHO), 1999)).

\begin{tabular}{ccc}
\hline \multirow{2}{*}{ Receiver-Receptor } & \multicolumn{2}{c}{ One-Hour $\mathbf{L}_{\text {Aeq }}(\mathrm{dB})$} \\
& Day & Night \\
& $\mathbf{0 7 : 0 0 - 2 2 : 0 0}$ & $\mathbf{2 2 : 0 0 - 0 7 : 0 0}$ \\
Residential; institutional; education & 55 & 45 \\
\hline Industrial, commercial & 70 & 70 \\
\hline
\end{tabular}

Table 4. Excerpt from the table "SEA objectives and indicators" related to noise. (Source: SEA for the Urban Plan of the Maestrale Ring wind farm).

\begin{tabular}{|c|c|c|c|}
\hline \multirow[b]{2}{*}{ Zone } & \multirow[b]{2}{*}{ Purpose of the Space } & \multicolumn{2}{|l|}{ Noise Level, $\mathrm{L}_{\text {Aeq }}(\mathrm{dB})$} \\
\hline & & $\begin{array}{l}\text { Day and Evening (Guidelines for Community } \\
\text { Noise, World Health Organization (WHO), 1999)) }\end{array}$ & Night \\
\hline 1 & $\begin{array}{l}\text { Areas for rest and recreation, hospital zones and } \\
\text { convalescent homes, cultural and historical sites, large } \\
\text { parks }\end{array}$ & 50 & 40 \\
\hline 2 & Tourist areas, camps and school zones & 50 & 45 \\
\hline 3 & Residential areas & 55 & 45 \\
\hline
\end{tabular}


Table 4. Cont.

\begin{tabular}{|c|c|c|c|}
\hline \multirow[b]{2}{*}{ Zone } & \multirow[b]{2}{*}{ Purpose of the Space } & \multicolumn{2}{|l|}{ Noise Level, $\mathrm{L}_{\text {Aeq }}(\mathrm{dB})$} \\
\hline & & $\begin{array}{l}\text { Day and Evening (Guidelines for Community } \\
\text { Noise, World Health Organization (WHO), 1999)) }\end{array}$ & Night \\
\hline 4 & $\begin{array}{l}\text { Business/residential and commercial/residential } \\
\text { areas and children's playgrounds }\end{array}$ & 60 & 50 \\
\hline 5 & $\begin{array}{l}\text { Town/city center, business, administrative zone with } \\
\text { apartments, zones along highways and roads }\end{array}$ & 65 & 55 \\
\hline 6 & $\begin{array}{l}\text { Industrial, storage and service areas and transport } \\
\text { terminals without residential buildings }\end{array}$ & $\begin{array}{c}\text { At the border of this zone, the noise must not exceed } \\
\text { value in the zone with which it borders }\end{array}$ & e limit \\
\hline
\end{tabular}

Modeling the spread of noise, i.e., prediction of the noise level from the planned Maestrale Ring wind farm was carried out in the program SoundPlan v.8.1, based on:

1. Sound emissions from the selected type of wind turbine;

2. A 3D digital model of the planning area;

3. The international standard ISO 9613 [59], with input settings and settings specially adapted to the assessment of noise from wind farms.

The ISO 9613 standard specifies an engineering method for calculating noise at a known distance from a variety of sources under meteorological conditions favorable to sound propagation. The standard defines favorable conditions as downwind propagation where the wind blows from the source to the receiver within an angle of $+/-45$ degrees from a line connecting the source to the receiver and at wind speeds appropriate for a specific project ( $10 \mathrm{~m} / \mathrm{s}$ for this SEA), measured at a hub height. To calculate far-field noise levels according to ISO 9613, the noise emissions of each turbine are firstly characterized in the form of octave band frequency levels. A series of octave band attenuation factors are then calculated for a range of effects including geometric divergence, air absorption, reflecting obstacles, screening, vegetation and ground reflections. The octave band attenuation fac-tors are then applied to the noise emission data to determine the corresponding octave band and total calculated noise level at receiver locations. Each wind turbine is modeled as a point source of sound. The total sound of the wind farm is then calculated on the basis of the simultaneous operation of all wind turbines and summing the contribution of each (Figures 2 and 3).

Modeling was carried out for a windspeed of $10 \mathrm{~m} / \mathrm{s}$ at the height of the wind turbine axis. This value was based on data from the anemometer poles used in the study on the potential of wind at the location of the planned Maestrale Ring wind farm, since it was determined that for $99 \%$ of the time, the wind measurement did not exceed $10 \mathrm{~m} / \mathrm{s}$ and so it was considered relevant for making the most unfavorable scenarios. The results are shown in Figure 2 for the day (and evening) period and in Figure 3 for the night period. A total of 8 sensitive receptors were selected in the surroundings of the planned Maestrale Ring wind farm and all of the sensitive receptors are situated in the north-western part of the wind farm, in the zone of the Stari Žednik settlement.

The results of the partial noise impact assessment for the planned Maestrale Ring wind farm are included in the semiquantitative multicriteria evaluation within the SEA. The results are shown below.

\section{Results}

The partial assessment of the increase in noise and its spatial dispersion as a consequence of the planned Maestrale Ring wind farm, shown in Figure 2, indicates that in the daytime (and evening) period, none of the sensitive receptors will be exposed to noise levels exceeding the permitted value, which for the day and evening is $55 \mathrm{~dB}(\mathrm{~A})$ for residential areas. With regard to noise during the night, from Figure 3 a somewhat different situation can be seen. Namely, it is evident that specific sensitive receptors, numbered 1,2, $3,4,7$ and 8, in Zone 4 are in the area where there is a noise limit level for the night period, 
which amounts to $45 \mathrm{~dB}(\mathrm{~A})$ for a residential area. The results of modeling indicate that this could be exceeded by as much as $3.5 \mathrm{~dB}$, which is considered just noticeable for the majority of people. It should be noted that this is a fairly low level of noise, which can be relatively easily "masked" by existing sources and levels of noise. The results of the partial noise assessment were incorporated into the multicriteria evaluation process in the SEA (Table 5).

Table 5. Excerpt from the table "SEA objectives and indicators" related to noise. (Source: SEA for the Urban Plan of the Maestrale Ring wind farm).

\begin{tabular}{|c|c|c|c|}
\hline Planning Solution & SEA Goal & $\begin{array}{l}\text { Rank (The Rank of the } \\
\text { Impacts Is Determined } \\
\text { According to the Criteria } \\
\text { from Table 2.) of the Impact }\end{array}$ & Explanation \\
\hline $\begin{array}{l}\text { Unit 1-Čantavir east } \\
\text { (46 wind turbines) }\end{array}$ & \multirow{4}{*}{ 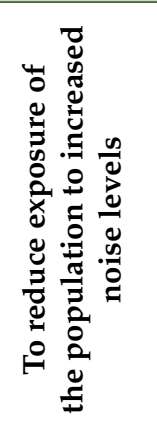 } & 0 & \multirow{2}{*}{$\begin{array}{l}\text { In units } 1 \text { and } 2 \text { no increase in the level of noise } \\
\text { above LVNI is expected, either for the } \\
\text { day/evening, or for the night period. }\end{array}$} \\
\hline $\begin{array}{l}\text { Unit } 2 \text {-Čantavir west } \\
\text { (30 wind turbines) }\end{array}$ & & 0 & \\
\hline $\begin{array}{l}\text { Unit } 3 \text {-Žednik north } \\
\text { (22 wind turbines) }\end{array}$ & & $\mathrm{L} /-2 / \mathrm{V} / \mathrm{P}$ & $\begin{array}{c}\text { In unit } 3 \text { it is expected that the LVNI will be } \\
\text { exceeded by } 3.5 \mathrm{~dB} \text { in the night period as a } \\
\text { consequence of the work of wind turbines } \\
\text { marked: VG48, VG51 and VG113 }\end{array}$ \\
\hline $\begin{array}{l}\text { Unit } 4 \text {-Žednik south } \\
\text { (15 wind turbines) }\end{array}$ & & 0 & $\begin{array}{l}\text { In unit } 4 \text { no increase in the value of noise levels } \\
\text { above LVNI is expected, either for the } \\
\text { day/evening or night period. }\end{array}$ \\
\hline
\end{tabular}

The results of the impact assessment, in addition to the matrix, are presented in the form of graphs for each planning solution evaluated. An example of a graph is shown in Figure 4 .

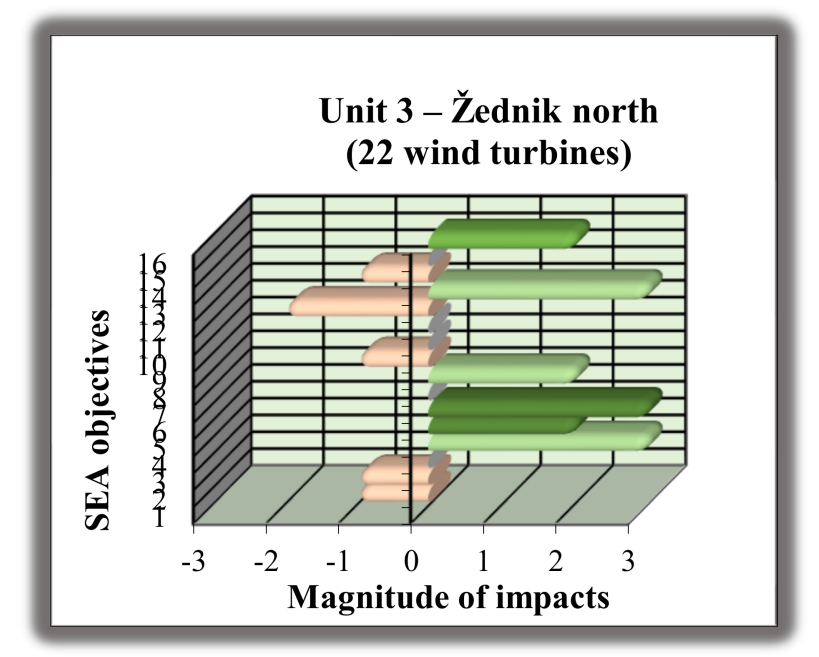

Figure 4. Results of modeling the spatial dispersion of noise for the night period.

The illustrative presentation of the evaluation results for the impact of the planned wind turbines in relation to the SEA objective "To reduce exposure of the population to increased noise levels" (Table 5), indicates that three positions of wind turbines can lead to exceeding the LVNI during the night period by $3.5 \mathrm{~dB}$, a value considered noticeable to most people [49].

Considering that exceeding the LVNI relates to the night period, which is a time of rest and that in this period in the subject area there is no continuous superposition of noise from other sources, but rather, the expected noise levels are exclusively a consequence of the planned wind farm, relocation of the following wind turbines was recommended: 
VG48, VG51 and VG113 (Figures 2 and 3), which the investor accepted. It is in this way that the SEA made the most significant contribution to preventive environmental protection in the earliest development phase of the planned Maestrale Ring wind farm project, the importance of which has already been written $[12,54]$. The new positions of the three wind turbines were determined and included in the urban plan, by harmonizing the results of the partial assessments carried out in relation to: noise, shadow flicker effect, the state of biodiversity and other spatial constraints in the planning area. In that way, the possible impact of noise from the planned wind farm on buildings and on the population was eliminated.

\section{Discussion}

Although some authors [35,60-67] confirm that the levels of infrasound pressure emitted by wind turbines are significantly below the generally accepted threshold of human hearing, which is why they cannot lead to negative health effects, other authors $[60,68-70]$, despite the lack of declared conclusive evidence that infrasound generated long-term by the work of wind turbines could be potentially harmful to human health especially in the low frequency range, also argue that there is no evidence to the contrary. Therefore, conclusions regarding such effects cannot be strictly determined, especially if we take into account the fact that people in the same area react differently to the presence of wind generators. What is certain, however, is that the impact of noise generated by wind farms should be viewed in the context of meeting the relevant values set by legislation and their impact in relation to noise considered in that context. The paper shows how the aspect of noise impact from wind farms can be considered in the SEA process.

The application of SEA in wind farm planning is based on guidelines for selecting optimal options to minimize or completely prevent potential conflicts in space that may occur in the correlation of wind farms with environmental elements, in this case in relation to generating noise. In this way, optimal options are sought at the earliest stage of project development, in order to eliminate risks in project financing that may occur at a later stage of project development, which is of particular importance to investors. Thus, the SEA applies the principle of preventive environmental protection in its full capacity and SEA stands out as an ideal instrument for assessing the spatial/territorial impacts of wind farms in the phase preceding the design and implementation (construction) of a specific investment project.

This situation is enabled by the specificity of planning wind farms, which also directly impacts the assessment of their environmental impact. Namely, in the earliest stages of development in wind farm projects, certain technical and spatial data are available that make various spatial analyses and modeling possible at the very beginning of the planning process, which is not usual for most planning documents, since they have more general planning solutions and a lack of technical details about their projects, preventing the quantification of results through different software models.

Due to the knowledge of certain technical details in planning wind farms, it is possible to check the suitability of the spatial determination for the wind turbines at the very beginning of a project's development. This means that there is no need to wait for the production of an EIA at the level of project documentation, because it brings certain risks for investors and for the project itself, given that at that stage the development of the project has already gone a long way. Namely, if the impact assessment is carried out only in the phase of producing project documentation, then the application of EIA/ESIA is the first and last opportunity to implement environmental protection policies in wind farm projects. At this point, it is very difficult to conceive sustainable solutions without financial consequences for investors, because the opportunity was missed at the very beginning of planning by applying SEA. It is therefore desirable to carry out continuous impact assessment in all phases of wind farm projects, a position held by the authors of this paper. This would start with the implementation of a preventive approach to protection using SEA in the earliest phase of project planning, followed by EIA/ESIA, which would be carried 
out to check the results of the SEA after selection of the specific type of wind turbine and which would also determine the technical measures of environmental protection during the preparation of project documentation.

In methodological terms, SEA is considered a comprehensive instrument that is predominantly based on expert qualitative evaluation of planning solutions, but in which there is flexibility and the possibility of applying different assessment methods, including partial assessments, which, however, must be incorporated into a comprehensive methodological SEA framework. With regard to wind farm projects, a so-called partial impact assessment can be carried out in the form of a special impact assessment and then incorporated into a holistic approach in the consideration of interactions between the existing and planned purposes for a particular area in the SEA process, as shown in this paper for the aspect of noise. It is also necessary in order to minimize subjectivity in the process of expert evaluation, the application of which is characteristic of SEA. These facts have an additional impact on the quality of the SEA process in the planning and spatial determination of wind farms and, thus, their importance in implementing these projects.

A particularly sensitive methodological step in the SEA is the selection of relevant evaluation criteria. In the case of noise impact assessment from the planned Maestrale Ring wind farm, the criteria for evaluating the impact of wind power on noise (Table 2) were based on a combination of quantitative and qualitative criteria (semi-quantitative method) and a partial noise impact assessment was carried out based on the results from the software model used and then incorporated into a matrix representation of multicriteria evaluation in SEA. This approach results in determining the ranks of the impacts, on the basis of which a decision is made on the acceptability of the proposed solutions, or a recommendation is made on the necessary spatial changes, which occurred in the case of the planned Maestrale Ring wind farm. The recommendation logically refers to the relocation of wind turbines that have an impact on selected receptors, in terms of increasing the value of noise intensity above the allowed levels.

The manner of presenting the results of the impact assessment in SEA (visualization) is particularly important for investors, as well as decision makers, who often have modest knowledge in this area and have a very important role in this final phase of the SEA process. Clear presentation of the results always contributes to a better understanding and impact assessment based on quantitative statements and modeling of the spatial dispersion of noise makes this possible.

\section{Conclusions}

The authors support the position that in order to increase objectivity in the SEA process, whenever possible, it is both desirable and significant to use simulation models that give quantitative results, even if this means a partial assessment for just one environmental element processed in SEA. In the case of wind farms, a partial quantitative impact assessment can be applied to the prediction of noise levels, shadow flicker effects and to some extent effects on ornithofauna and chiropterofauna.

In this particular case, the essence of the SEA process in Maestrale Ring wind farm planning is that after defining the initial positions of wind turbines based on wind potential, their final position is harmonized with the results of partial wind power impact assessments, which has been elaborated in this paper in relation to noise. After these checks, based on the most unfavorable scenario, it is possible to reliably conclude which wind turbines do not have the optimal position and to correct their position in order to eliminate negative impacts. In this way, potential negative spatial/territorial impacts are eliminated in the planning process and in the SEA and further development of the project, as well as preparation of the EIA/ESIA study can be approached in a relaxed manner by the investor, the creditor and the experts involved.

The negative context of applying SEA generally refers to assessing aspects of possible impacts for which it is not possible to perform a quantitative partial assessment based on the application of software models, but they are part of the universal semiquantitative 
method of multicriteria evaluation in SEA. In the case of wind farms, this is certainly not the aspect of noise, but it can, for example, be an assessment of the impact on the landscape, which otherwise represents a subjective category, because it depends on the perception of the observer, so it would be hard to avoid subjectivity in the evaluation. In this context, it is necessary to apply optimal techniques and tools within the SEA that will achieve the greatest possible objectivity in the assessment of environmental impact (simulation models, GIS technologies, etc.).

With regard to subjectivity in decision making based on the results of the SEA process, it is beyond the reach of experts in this field and depends on political, financial and other aspects, which can certainly be a threat to the implementation of the SEA propositions.

However, when subjectivity in the SEA process is minimized in the way elaborated in the paper, the expected contribution to optimal decision making as the ultimate role of the SEA process takes on a new dimension, because expert arguments based on quantitative statements are always difficult for decision makers to challenge.

Author Contributions: Writing_original draft preparation, review and editing B.D.J.; software, modelling and visualiza-tion, A.C.; validation and formal analysis, B.M.; All authors have read and agreed to the published version of the manuscript.

Funding: This research received no external funding.

Institutional Review Board Statement: Not applicable.

Informed Consent Statement: Not applicable.

Data Availability Statement: Not applicable.

Acknowledgments: Thank you to the Vetropark Maestrale Ring Company d.o.o. for their collaboration in the application of the SEA process to the Maestrale Ring wind farm project. This paper is a result of a research supported by the Ministry of Education, Science and Technological Development of the Republic of Serbia (Contract number 451-03-9/2021-14/200006).

Conflicts of Interest: The authors declare no conflict of interest.

\section{List of Nomenclature/Abbreviations}

$\begin{array}{ll}\text { SEA } & \text { Strategic Environmental Assessment } \\ \text { WHO } & \text { World Health Organization } \\ \text { EIA } & \text { Environmental Impact Assessment } \\ \text { ESIA } & \text { Environmental and Social Impact Assessment } \\ \text { LCA } & \text { Life Cycle Assessment } \\ \text { IFC } & \text { International Financial Institution } \\ \text { EHS Guidelines } & \text { Environmental, Health and Safety Guidelines } \\ \text { ISO } & \text { International Organization for Standardization } \\ \text { LVNI } & \text { Limit values for the noise indicators } \\ \text { GIS } & \text { Geographical Information System }\end{array}$

\section{References}

1. Partidario, M.R. Strategic environmental assessment: Key issues emerging from recent practice. Environ. Impact Assess. Rev. 1996, 16, 31-55. [CrossRef]

2. Therivel, R. Strategic Environmental Assessment in Action, 2nd ed.; Taylor and Francis: New York, NY, USA, 2013 ; pp. 57-74.

3. Therivel, R.; Partidario, M.R. The Practice of Strategic Environmental Assessment, 1st ed.; Taylor and Francis: New York, NY, USA, 1996; pp. 1-14.

4. Nilsson, M.; Dalkmann, H. Decision-making and Strategic Environmental Assessment. J. Environ. Assess. Policy Manag. 2001, 3, 305-327. [CrossRef]

5. Nilssona, M.; Björklund, A.; Finnveden, G.; Johansson, J. Testing an SEA methodology for the energy sector: A waste incineration tax proposal. Environ. Impact Assess. Rev. 2005, 25, 1-32. [CrossRef]

6. Maričić, T.; Josimović, B. Overview of Strategic Environmental Assessment (SEA) systems in SEE countries. Archit. Urban. 2005, 16-17, 66-74. 
7. Crnčević, T.; Marić, I.; Josimović, B. Strategic environmental assessment and climate change in the Republic of Serbia: Support to development and adjustment process. Spatium 2011, 26, 14-19. [CrossRef]

8. White, L.; Noble, B. Strategic environmental assessment for sustainability: A review of a decade of academic research. Environ. Impact Assess. Rev. 2012, 42, 60-66. [CrossRef]

9. Nenković-Riznić, M.; Josimović, B.; Milijić, S. SEA as Instrument in Responsible Planning of Tourist Destinations. Case Study of Djerdap National Park, Serbia. J. Environ. Tour. Anal. 2014, 2, 5-18.

10. Krunić, N.; Josimović, B.; Gajić, A.; Nenković-Riznić, M. Territorial analysis as support to the strategic environmental assessment process for agro-waste management planning. Spatium 2019, 42, 16-22. [CrossRef]

11. Josimović, B.; Krunić, N.; Gajić, A.; Manić, B. Multi-criteria Evaluation in Strategic Environmental Assessment in the Creation of a Sustainable Agricultural Waste Management Plan for wineries: Case Study: Oplenac. J. Agric. Environ. Ethics. 2021, 34, 4. [CrossRef]

12. Josimović, B.; Cvjetić, A.; Furundžić, D. Strategic Environmental Assessment and the precautionary principle in the spatial planning of wind farms-European experience in Serbia. Renew. Sustain. Energy Rev. 2021, 136, 110459. [CrossRef]

13. EUR-Lex. European Strategic Environmental Assessment Directive 2001/42/ EC. Available online: https: / / eur-lex.europa.eu/ eli/dir/2001/42/oj (accessed on 21 July 2021).

14. UNECE. The Protocol on Strategic Environmental Assessment. Available online: https://unece.org/DAM/env/eia/documents/ legaltexts / protocolenglish.pdf (accessed on 21 July 2021).

15. Salhofer, S.; Wassermann, G.; Binner, E. Strategic environmental assessment as an approach to assess waste management systems. Experiences from an Austrian case study. Environ. Model. Softw. 2007, 22, 610-618. [CrossRef]

16. Ahmed, K.; Mercier, J.R. Strategic Environment Assessment at the World Bank. In Proceedings of the 8th Intergovernmental Policy Forum on Environmental Assessment, Vancouver, BC, Canada, 25 April 2004; Canadian Environmental Assessment Agency: Ottawa, ON, Canada, 2004.

17. Clayton, B.; Sadler, B. Strategic Environmental Assessment: A Sourcebook and Reference Guide to International Experience; Earthscan: London, UK, 2005.

18. European Commission. EU Guidance on Wind Energy in Accordance with the EU Nature Legislation. Available online: https:/ / ec.europa.eu/environment/nature/natura2000/management/docs/wind_farms_en.pdf (accessed on 23 July 2021).

19. Zohbi, G.; Hendrick, P.; Bouillard, P. Evaluation of the impact of wind farms on birds: The case study of Lebanon. Renew. Energy 2015, 80, 682-689. [CrossRef]

20. Garcia, D.A.; Bruschia, D. A risk assessment tool for improving safety standards and emergency management in Italian onshore wind farms. Sustain. Energy Technol. Assess. 2016, 18, 48-58.

21. Gallo, P.; Fredianelli, L.; Palazzuoli, D.; Licitra, G.; Fidecaro, F. A procedure for the assessment of wind turbine noise. Appl. Acoust. 2016, 114, 213-217. [CrossRef]

22. Lenchine, V. Assessment of amplitude modulation in environmental noise measurements. Appl. Acoust. 2016, 104, 152-157. [CrossRef]

23. Zhang, Y.; Tang, N.; Niu, Y.; Du, X. Wind energy rejection in China: Current status, reasons and perspectives. Renew. Sustain. Energy Rev. 2016, 66, 322-344. [CrossRef]

24. Maslov, N.; Claramunt, C.; Wanga, T.; Tanga, T. Method to estimate the visual impact of an offshore wind farm. Appl. Energy 2017, 204, 1422-1430. [CrossRef]

25. Newson, S.; Evansa, H.; Gillingsa, S.; Jarretta, D.; Raynor, R.; Wilsona, M. Large-scale citizen science improves assessment of risk posed by wind farms to bats in southern Scotland. Biol. Conserv. 2017, 215, 61-71. [CrossRef]

26. Farfán, M.; Duarte, J.; Real, R.; Muñoz, A.; Fa, J.; Vargas, J. Differential recovery of habitat use by birds after wind farm installation: A multi-year comparison. Environ. Impact Assess. Rev. 2017, 64, 8-15. [CrossRef]

27. Roemer, C.; Disca, T.; Coulonac, A.; Basac, Y. Bat flight height monitored from wind masts predicts mortality risk at wind farms. Biol. Conserv. 2017, 215, 116-122. [CrossRef]

28. Parisé, J.; Walker, T.R. Industrial wind turbine post-construction bird and bat monitoring: A policy framework for Canada. J. Environ. Manag. 2017, 201, 252-259. [CrossRef]

29. Josimović, B. Implementation of Environmental Management System in Spatial Planning; University of Belgrade: Belgrade, Serbia, 2008. Available online: http:/ / raumplan.iaus.ac.rs/handle/123456789/544 (accessed on 15 August 2021).

30. Pedersen, E.; Waye, K.P. Wind turbine noise, annoyance and self-reported health and well-being in different living environments. Occup. Environ. Med. 2007, 64, 480-486. [CrossRef]

31. Dusseldorp, A.; Houthuijs, D.; van Overveld, A.; van Kamp, I.; Marra, M. Handreiking Geluidhinder Wegverkeer: Berekenen en Meten. RIVM rapport. 2011. Available online: https://rivm.openrepository.com/bitstream/handle/10029/261516/609300020 .pdf? sequence=3\&isAllowed $=y$ (accessed on 17 August 2021).

32. Iannace, G.; Cooper, S. Acoustics 2020, Special Issue Wind Turbine Noise. Available online: https://www.mdpi.com/journal/ acoustics/special_issues/wind_tturbine_noise (accessed on 17 August 2021).

33. Moller, H.; Pedersen, C.S. Hearing at low and infrasonic frequencies. Noise Health 2004, 6, 37. [PubMed]

34. Merlin, T.; Newton, S.; Ellery, B.; Milverton, J.; Farah, C. Systematic Review of the Human Health Effects of Wind Farms; National Health and Medical Research Council: Canberra, Australia, 2013. 
35. Berger, R.G.; Ashtiani, P.; Ollson, C.A.; Aslund, M.W.; McCallum, L.C.; Leventhall, G.; Knopper, L.D. Health-based audible noise guidelines account for infrasound and low-frequency noise produced by wind turbines. Front. Public Health 2015, 3, 3. [CrossRef] [PubMed]

36. Cooper, K.; Kirkpatrick, P.; Stewart, A. Health effects associated with working in the wind power generation industry: A comprehensive systematic review. JBI Libr. Syst. Rev. 2014, 12, 327-373.

37. Tonin, R. A review of wind turbine-generated infrasound: Source, measurement and effect on health. Acoust. Aust. 2018, 46, 69-86. [CrossRef]

38. Hansen, C.; Zajamšek, B.; Hansen, K. Infrasound and low-frequency noise from wind turbines. Lect. Notes Mech. Eng. 2016, 3-16. [CrossRef]

39. Gortsas, T.V.; Triantafyllidis, T.; Chrisopoulos, S.; Polyzos, D. Numerical modelling of micro-seismic and infrasound noise radiated by a wind turbine. Soil Dyn. Earthq. Eng. 2017, 99, 108-123. [CrossRef]

40. Zagubien, A.; Wolniewicz, K. The impact of supporting tower on wind turbine noise emission. Appl. Acoust. 2019, 155, 260-270. [CrossRef]

41. Adewumi, G.; Nyamayoka, L.T.E.; Inambao, F. Reducing infrasound and low frequency noise from wind turbine blades and rotors using ANC. Renew. Bioresour. 2015, 3, 3. [CrossRef]

42. Zajamšek, B.; Hansen, K.L.; Doolan, C.J.; Hansen, C.H. Characterisation of wind farm infrasound and low-frequency noise. J. Sound Vib. 2016, 370, 176-190. [CrossRef]

43. Sedaghatizadeh, N.; Arjomandi, M.; Cazzolato, B.; Kelso, R. Wind farm noises: Mechanisms and evidence for their dependency on wind direction. Renew. Energy 2017, 109, 311-322. [CrossRef]

44. Søndergaard, B. Low frequency noise from wind turbines: Do the Danish regulations have any impact? An analysis of noise measurements. Int. J. Aeroacoustics 2015, 14, 909-915. [CrossRef]

45. Møller, H.; Pedersen, C.S. Low-frequency noise from large wind turbines. J. Acoust. Soc. Am. 2011, 129, 3727-3744. [CrossRef] [PubMed]

46. Freiberg, A.; Schefter, C.; Girbig, M.; Murta, V.C.; Seidler, A. Health effects of wind turbines on humans in residential settings: Results of a scoping review. Environ. Res. 2019, 169, 446-463. [CrossRef] [PubMed]

47. Boczar, T.; Zmarzły, D.; Kozioł, M.; Wotzka, D. The application of time-frequency ridge transformation for the analysis of infrasound signals generated by wind turbines. Appl. Acoust. 2021, 177, 107961. [CrossRef]

48. European Commission. Environmental Noise Directive (2002/49/EC). Available online: https://eur-lex.europa.eu/legalcontent/EN/TXT/?uri=CELEX:32002L0049 (accessed on 21 August 2021).

49. WHO. Guidelines for Community Noise. Available online: https://www.who.int/docstore/peh/noise/Comnoise-1.pdf (accessed on 21 August 2021).

50. Brown, A.L.; Therivel, R. Principles to guide the development of strategic environmental assessment. Impact Assess. Proj. Apprais. 2000, 18, 183-189. [CrossRef]

51. Balfors, B.; Wallström, J.; Lundberg, K.; Söderqvist, T.; Hörnberg, C.; Högström, J. Strategic environmental assessment in Swedish municipal planning. Trends and challenges. Environ. Impact Assess. Rev. 2018, 73, 152-163. [CrossRef]

52. Unalan, D.; Cowell, R. Strategy, context and strategic environmental assessment. Environ. Impact Assess. Rev. 2019, $79,106305$. [CrossRef]

53. Marsden, S. Strategic environmental assessment: An international overview. Strategic environmental assessment in Australasia. J. Environ. Assess. Policy Manag. 2002, 4, 31-66. [CrossRef]

54. Josimović, B. Spatial Aspects of the Impact of Wind Farms on the Environment; IAUS: Belgrade, Serbia, 2020; pp. 1-184. Available online: http:/ / raumplan.iaus.ac.rs/handle/123456789/545 (accessed on 18 July 2021).

55. Republic of Serbia-Ministry of Environmental Protection. Law on Environmental Noise Protection (Official Gazette of RS, no. 36/2009 and 88/2010). Available online: https://www.ekologija.gov.rs/sites/default/files/old-documents/Buka/Zakoni/ Zakon\%20o\%20zastiti\%20od\%20buke.pdf (accessed on 19 June 2021).

56. Republic of Serbia-Ministry of Environmental Protection. Regulation on Noise Indicators, Limit Values, Methods for Assessing Noise Indicators, Harassment and Harmful Effects of Noise in the Environment (Official Gazette of RS, no. 75/2010). Available online: https:/ / www.ekologija.gov.rs/sites/default/files/old-documents/Buka/Uredbe/uredba.pdf (accessed on 19 June 2021).

57. International Finance Corporation-WB Group. Performance Standard 1-Social and Environmental Assessment and Management Systems; Environmental, Health, and Safety (EHS) Guidelines, 1. Environmental—1.7 Noise (2007). Available online: https:/ / www.ifc.org/wps/wcm/connect/4a4db1c5-ee97-43ba-99dd-8b120b22ea32/1-7\%2BNoise.pdf?MOD=AJPERES\& CVID $=1$ s4XYBw (accessed on 23 August 2021).

58. ISO 1996-1:2016. Acoustics—Description, measurement and assessment of environmental noise_Part 1: Basic quantities and assessment procedures, ISO 1996-2:2017 Acoustics—description, measurement and assessment of environmental noise—Part 2: Determination of sound pressure levels; International Organization for Standardization: Geneva, Switzerland, 2016.

59. ISO 9613-1:1993. Acoustics—Attenuation of Sound during Propagation Outdoors—Part 1: Calculation of the Absorption of Sound by the Atmosphere; ISO 9613-2:1996 Acoustics-Attenuation of Sound during Propagation Outdoors-Part 2: General Method of Calculation; International Organization for Standardization: Geneva, Switzerland, 1993.

60. Farboud, A.; Crunkhorn, R.; Trinidade, A. Wind turbine syndrome: Fact or fiction? J. Laryngol. Otol. 2013, 127, 222-226. [CrossRef] 
61. Doolan, C. A review of wind turbine noise perception, annoyance and low frequency emission. Wind. Eng. 2013, 37, 97-104. [CrossRef]

62. McCunney, R.J.; Mundt, K.A.; Colby, W.D.; Dobie, R.; Kaliski, K.; Blais, M. Wind turbines and health: A critical review of the scientific literature. Int. J. Occup. Environ. Med. 2014, 56, e108-e130. [CrossRef]

63. O'Neal, R.D.; Hellweg, R.D.; Lampeter, R.M. Low frequency noise and infrasound from wind turbines. Noise Control. Eng. J. 2011, 59, 135. [CrossRef]

64. Pleban, D.; Radosz, J.; Smagowska, B. Noise and Infrasonic Noise at Workplaces in a Wind Farm. Arch. Acoust. 2017, 42, 491-498. [CrossRef]

65. Knopper, L.D.; Ollson, C.A. Health effects and wind turbines: A review of the literature. Environ. Health 2011, 10, 78. [CrossRef] [PubMed]

66. Kurpas, D.; Mroczek, B.; Karakiewicz, B.; Kassolik, K.; Andrzejewski, W. Health impact of wind farms. Ann. Agric. Environ. Med. 2013, 20, 595-604. [PubMed]

67. Leventhall, G. Infrasound from wind turbines-Fact, fiction or deception. Can. Acoust. 2006, 34, $29-36$.

68. Bell, J.A. Annoyance from wind turbines: Role of the middle ear muscles. Acoust. Aust. 2014, 42, 57.

69. Jeffery, R.D.; Krogh, C.M.E.; Horner, B. Industrial wind turbines and adverse health effects. Can. J. Rural Med. 2014, 19, 21-26.

70. Salt, A.N.; Kaltenbach, J.A. Infrasound from wind turbines could affect humans. Bull. Sci. Technol. Soc. 2011, 31, 296-302. [CrossRef] 